\title{
Plasmodium vivax infection: atypical memory $B$ cells are expanded and associated with the persistence of Duffy binding protein II (DBPII) antibody response
}

Flora S Kano ${ }^{1 *}$, Barbara AS Lima ${ }^{1}$, Michaelis L Tang ${ }^{1}$, Pedro AC Costa ${ }^{1}$, Cor JF Fontes ${ }^{2}$, Bruno M Sanchez ${ }^{2}$, Roberto S Rocha ${ }^{1,3}$, Irene S Soares ${ }^{4}$, Cristiana FA Brito ${ }^{1}$, Lis Antonelli', Luzia H Carvalho'

From Challanges in malaria research: Core science and innovation

Oxford, UK. 22-24 September 2014

Antibody responses generated during malaria infection represent an important component of acquired clinical immunity. Despite that, B cell subpopulations induced by the Plasmodium vivax $(\mathrm{Pv})$ infection remains largely unknown. Here, we demonstrated that activated as well as "atypical" memory B cells (MBCs) are expanded in peripheral blood of $P v$-exposed individuals, but their frequencies were not associated with acute infection. Aiming to investigate the association between peripheral $\mathrm{B}$ cells subsets and $P v$-specific antibodies, we further followed-up 34 individuals exposed to P. vivax in the Brazilian Amazon area, an area of markedly unstable malaria transmission; after three cross-sectional survey (at 6-months intervals), ELISAdetected specific IgG (AMA-1, MSP1-19, DBPII) allowed the classification of those individuals as non-responder (NR), temporary (TR) or persistent responder (PR). For AMA-1 and MSP1-19 serological groups, the frequencies of MBCs (classical and atypical) and plasma cells (PCs) were similar among the groups. For DBPII group, we found a trend toward decreases classical MBCs according to the antibody response (NR $>\mathrm{TR}>\mathrm{PR})$. On the other hand, the frequencies of atypical MBCs increased according to the presence and persistence of DBPII antibody response $(\mathrm{PR}>\mathrm{TR}>\mathrm{NR})$. Altogether, these results showed that atypical MBCs are expanded in Pv-exposed individuals (infected and non-infected), and it seems to be associated with the persistence of DBPII antibody response. Although preliminary, these results suggest that atypical MBCs contribute in generation of malarial antibody responses and provide

${ }^{1}$ Centro de Pesquisas René Rachou/FIOCRUZ, Belo Horizonte, MG, Brazil Full list of author information is available at the end of the article insight into the role of atypical MBCs in P. vivax malaria immunity.

\section{Acknowledgements}

Supported by: FAPEMIG, FIOCRUZ, PAPES VI/FIOCRUZ.

\section{Authors' details}

${ }^{1}$ Centro de Pesquisas René Rachou/FIOCRUZ, Belo Horizonte, MG, Brazil. ${ }^{2}$ Universidade Federal do Mato Grosso, Cuiabá, MT, Brazil. ${ }^{3}$ Instituto de Pesquisas Leônidas e Maria Deane/FIOCRUZ, Manaus, AM, Brazil.

${ }^{4}$ Universidade de São Paulo, São Paulo, SP, Brazil.

Published: 22 September 2014

doi:10.1186/1475-2875-13-S1-P52

Cite this article as: Kano et al:: Plasmodium vivax infection: atypical memory B cells are expanded and associated with the persistence of Duffy binding protein II (DBPII) antibody response. Malaria Journal 2014 13(Suppl 1):P52.

Submit your next manuscript to BioMed Central and take full advantage of:

- Convenient online submission

- Thorough peer review

- No space constraints or color figure charges

- Immediate publication on acceptance

- Inclusion in PubMed, CAS, Scopus and Google Scholar

- Research which is freely available for redistribution 